\title{
Contribution of Former Poachers for Wildlife Conservation in Rwanda Volcanoes National Park
}

\section{Pacifique Uwayo, Vincent Martin Nsanzumukiza*, Abias Maniragaba, Alexandre Prince Nsabimana, Victoire Akimanizanye}

Department of Environmental Economics and Natural Resources Management, Faculty of Environmental Studies, University of Lay Adventists of Kigali, Kigali, Rwanda

Email: ^nsanzumumartiv@gmail.com

How to cite this paper: Uwayo, P., Nsanzumukiza, V. M., Maniragaba, A., Nsabimana, A. P., \& Akimanizanye, V. (2020). Contribution of Former Poachers for Wildlife Conservation in Rwanda Volcanoes National Park. Journal of Geoscience and Environment Protection, 8, 47-56.

https://doi.org/10.4236/gep.2020.84004

Received: March 14, 2020

Accepted: April 13, 2020

Published: April 16, 2020

Copyright $\odot 2020$ by author(s) and Scientific Research Publishing Inc. This work is licensed under the Creative Commons Attribution International License (CC BY 4.0).

http://creativecommons.org/licenses/by/4.0/

(c) (i) Open Access

\begin{abstract}
This study assessed the contribution of former poachers to wildlife conservation in Volcanoes National Park, the main causes of poaching activities in Volcanoes National Park. The results indicated that the main causes of poaching and other illegal activities are associated with poverty, ignorance and culture and commercial purposes. The results further illustrated that poaching cases decreased in the Volcanoes National Park where, from 2018, the snares removed from the park reduced from above 1000 to 600 snares. In the same year, only 3 poachers from Kinigi and Shingiro Sectors were arrested. The findings illustrated that introducing of revenue sharing scheme where, $10 \%$ of the park's revenues are shared to the local communities living adjacent to the park, and constructing a buffalo wall stone around the Volcanoes National Park are of the important measures which contributed to solve completely the problems of poaching and human-wildlife conflicts in the volcanic area. However, some respondents reported that the construction of buffalo wall did not prevent animal from escaping the park, they have proposed the construction of strong fence such as electrically fenced wall.
\end{abstract}

\section{Keywords}

Poaching Activities, Former Poachers, Wildlife Conservation, Ecosystem Stability

\section{Introduction}

Globally, more efforts to address poaching and wildlife trafficking have evolved over time and focused upon reducing both the supply and demand aspects of the 
illegal wildlife trade (Njuguna \& Deisser, 2016). Until the $20^{\text {th }}$ century, the poaching activities were subsistence (Richard, 2000). However, the poaching activities were eradicated through enforcement of the exclusive rights to hunt animals and fish and poaching was a serious crime punishable by imprisonment (Matinca, 2018). The law restricting poaching and other illegal activities and hiring gamekeepers were passed in the $17^{\text {th }}$ and $18^{\text {th }}$ centuries (Murali, 2017). At present, about 23\% (1130 species) of mammals and 12\% (1194 species) of birds are considered as threatened (Maingi et al., 2012). Land conversion by humans, resulting in natural habitat loss, is most evident in tropical forests. Air pollution and the introduction of damaging alien species are also considered as threats to animals (Mentan, 2017). Other causes of species loss include the ongoing growth of human populations and unsustainable consumer lifestyles, increasing production of waste and pollutants, urban development, and international conflicts (Lewis et al., 2017). In Africa, the enforcing game codes have led to the critical depletion of the rhinoceros for its horn, and the African elephant for its ivory (Warchol, 2017). The Bengal tiger of India and the Gorilla of central Africa have similarly been threatened and heavily poached for their meat, organs, skin, scales and other parts of the body valued for use in traditional medicine; as a result, populations of these species have fallen dramatically during the early $21^{\text {st }}$ century, and they are listed as endangered or critically endangered species (Jones et al., 2012). Plants are also susceptible to poaching, even when forests are not completely cleared, particularly valuable trees such as rosewood or mahogany may be illegally logged from an area, eliminating both tree species and all animals that depend on it (Schauer, 2019). Some species are illegally collected not to be killed but to be kept alive and sold as ornamental plants, and the survival of various carnivorous plants, cycads, cacti, and orchid species is threatened by collectors (Schauer, 2019). To reduce poaching activities and their effects on wildlife species, game management and other conservation programs throughout the world have been introduced to overcome the effects of poaching and other threats to wildlife. The former poachers are hired as park rangers to ensure their livelihood change (Beck et al., 2019).

The wildlife tourism form provides local economic benefits through the maintaining wildlife integrity (Munanura et al., 2016). The wildlife tourism has triggered the establishment of tourism revenue sharing (TRS) programs across Africa, which is designed to reduce poverty (Archabald \& Naughton-Treves, 2001).

In Rwanda, local communities around national parks are given by Rwanda Development Board (RDB) 10\% of the park's revenue through Revenue Sharing Program. This rate was increased from 5\% (Kagarama et al., 2012), after the increase of gorilla permit from $\$ 750$ to $\$ 1500$ in 2018 (Imanishimwe et al., 2018). Rwanda Development Board's decision of restructuring its Revenue Sharing Scheme was taken as a response to the suggestions of the previous researchers (Munanura et al., 2016), who identified that the 5\% given to local communities had minimal conservation impacts due to acute food insecurity and limited livelihood capabilities among the poorest residents in proximity to Volcanoes $\mathrm{Na}$ - 
tional Park. Suggesting the increase of the percentage of the amount given to the local communities, researchers were expecting that it could help Rwanda Development Board (RDB) to achieve both short-term and long-term conservation goals, consideration of wildlife conservation linkages and to ensure active participation of the most economically disadvantaged residents in proximity to the park boundary (Munanura et al., 2016). Indeed, this program plays a big role in eradicating the problem of poaching in the parks. Therefore, the focus of this study is related to the Volcanoes National Park, a habitat of different wildlife species including the rare endangered mountain gorillas currently found in three countries worldwide namely: Rwanda, Uganda, and the Democratic Republic of Congo (DRC). Significant revenue from mountain gorilla tourism has motivated the government of Rwanda to protect wildlife using strict protectionism measures to conservation. With the undertaken measures, the rate of poaching activities in the Volcanoes National Park has decreased year by year. Therefore, this paper aimed at evaluating the former poacher's contribution to wildlife conservation in the Volcanoes National Park and assesses the main causes of poaching activities.

\section{Materials and Methods}

\subsection{Study Area Description}

The research was conducted in Kinigi Sector at two different places namely: Gorilla Guardian Village and Rwanda Tourism Information Center located in the Northern Province of Rwanda, specifically in Musanze District; the Rwanda's most mountainous district, containing the largest part of the Volcanoes National Park. Five of the eight volcanoes of the Virunga chain (Karisimbi, Bisoke, Sabyinyo, Gahinga and Muhabura) are within the district boundaries. The District capital serves as a hub for tourists. Kinigi Sector is adjacent to the Volcanoes National Park, which is the habitat of the rare endangered mountain gorillas (Rwanda's current leading foreign exchange earner) and other wildlife species including the golden monkeys, buffaloes, elephants and bamboo trees which have been threatened by poachers whose majority are from local communities living near the park. The population census of 2012 indicated that the sector was populated by 27,221 people on the total area of $80.7 \mathrm{Km}^{2}$ and the population density of $337.2 / \mathrm{km}^{2}$.

Kinigi Sector is subdivided into 5 cells (Kaguhu, Bisate, Nyonirimia, Nyabigoma and Kampanga), Figure 1 and forty villages commonly called imidugudu. Its administrative office is located in Nyagisenyi Village in Nyonirima Cell. Its boundaries are limited in the North by the Volcanoes National Park, in the South and the East by Nyange Sector and in the West by Shingiro Sector, the Volcanoes National Park's Head Office is located in Kinigi Sector.

The area experiences seasonal temperature variations with the highest temperatures occurring during the dry season and the coldest occur during the rainy season. The average maximum temperature ranges between $22^{\circ} \mathrm{C}-26^{\circ} \mathrm{C}$ while 


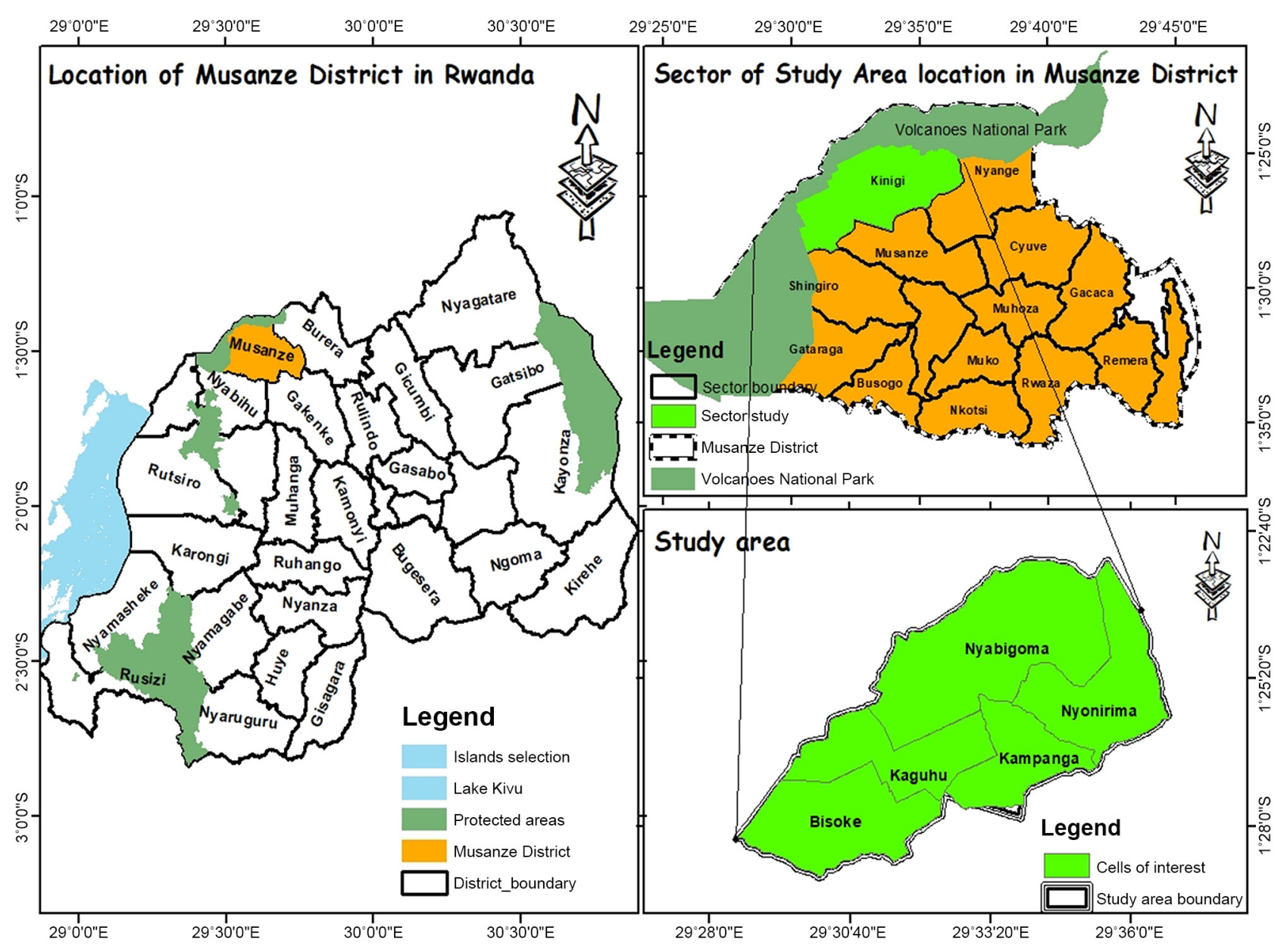

Figure 1. Geographical map of Rwanda and Musanze District.

the average minimum temperature ranges between $10^{\circ} \mathrm{C}-15^{\circ} \mathrm{C}$, which is dispersed over four main seasons: a short dry season from January to March, a short rainy season from March to May, characterized by torrential rainfall, a long dry season from June to August and a long rainy season from September to December. It experiences typical tropical climate which is characterized by high annual rainfall of up to $1500 \mathrm{~mm}$ per year for the northwest volcanic areas (William, 2018).

\subsection{Sample and Data Collection Techniques}

Selection of sample size from 45 members of Gorilla Guardian Village and 40 staff of Rwanda Tourism Information Center was done through the use of Slovin's formula (Slovin, 1960).

$$
n=\frac{N}{1+N(e)^{2}}
$$

$n=$ Sample size;

$N=$ Population size;

$e=$ Error tolerance. 
With confidence level of $99 \%$ which gives a confidence coefficient of 0.99 and a margin error of 0.1 , with this formula, a sample size of 59 respondents was selected, Table 1. On the other side, 6 local authorities were selected (1 Executive Secretary of Kinigi Sector and 5 Executive Secretaries of five Cells of this Sector).

During the data collection, the techniques such as field visit and observation, group discussions, and self-administered questionnaire were used. Data related to the poachers and snares trends were collected from the Rwanda Development Board (RDB). Descriptive research design was applied to gather data from the sample size of 65 respondents who were randomly selected from three categories of study populations (Gorilla Guardian Village, Local authorities and Tourism Information Center) of 91 people. The data were treated statistically with SPSS Software.

\section{Results and Discussions}

\subsection{The Major Causes of Poaching and Other Illegal Activities}

Based on the research findings, the main causes of poaching and other illegal activities are not the same; some people reported poverty and culture as the main causes while others focused on human wildlife conflict, Table 2, previous research confirmed various reasons of poaching in the entire world (Beck et al., 2019). Poverty, ignorance (low level of education and lack of awareness), culture, poor management of wildlife natural habitats, population growth of citizens versus land availability, corruption, and weakness of nations in terms of law enforcement of the wildlife trafficking are the major causes, Table 2, this has been confirmed with previous research (Beck et al., 2019).

Table 1. Sample size.

\begin{tabular}{ccc}
\hline Population categories & Population size & Sample size \\
\hline Gorilla Guardian Village & 45 & 31 \\
Rwanda Tourism Information Center & 40 & 28 \\
Local authorities & 6 & 6 \\
Total & 91 & $\mathbf{6 5}$ \\
\hline
\end{tabular}

Table 2. The main causes of poaching in the Volcanoes National Park.

\begin{tabular}{ccc}
\hline Main causes of poaching provided by Gorilla Guardian Village & Frequency & Percentage \% \\
\hline Culture & 13 & 22 \\
Poverty & 11 & 19 \\
$\begin{array}{c}\text { Animals that escape the park and damage local communities' } \\
\text { properties as a result of poor management of the park }\end{array}$ & 14 & 24 \\
Commercial purposes & 9 & 15 \\
Ignorance (lack of knowledge about the role of wildlife) & 12 & 20 \\
Total & 59 & 100 \\
\hline
\end{tabular}


Contrary, the situation is opposite in some countries like China and North America where, poaching is mostly done with the influences of the richest people for commercial purposes, trophies, and pleasure (Collins \& Kays, 2011). The situation in other countries, poverty and poor job opportunities have pushed local people in harvesting wildlife and performing other illegal activities in the protected areas as their sources of income. For the major causes of poaching activities, the reality is that they are not the same in both developed and developing countries (Knapp et al., 2017).

\subsection{Current Situation of Poaching in the Volcanoes National Park}

For the current situation of wildlife conservation in the Volcanoes National Park, the research results indicated that the wildlife conservation measures undertaken by the Rwandan Government, have been fruitful and at present, poaching activities in the park have reduced clearly where from 2018, the number of snares removed from the Volcanoes National Park reduced from above 1000 snares to 600 snares (Figure 2).

In Shingiro Sector, the numbers of poachers recorded are still high compared to other sectors adjacent to the Volcanoes National Park and the reason for these high poaching activities is related to high population of BASANGWABUTAKA whose majority are uneducated people and consider poaching in their culture. This sector is also located nearby the Democratic Republic of Congo (DRC) where, wildlife conservation is very difficult due to security issue in the Virunga National Park. The highest numbers of poachers (18 poachers) were recorded in Shingiro sector in 2013 as it is illustrated in Table 3. Indeed, with the government efforts in wildlife conservation, poaching activities are declining in the volcanic area and the tangible proof is the increase of mountain gorillas' number in the park, where since the introduction of the "Gorilla Naming Ceremony" in 2005, over 258 baby gorillas have been given names and at present, the park accommodates over 350 gorillas (Samedi et al., 2019). Table 3 illustrates the number of snares removed and the fluctuation of poachers arrested from 2006 until 2018 in different sectors of Musanze District.

The findings indicated that the number of poachers has reduced along period of time due to different measures such as patrol, arresting of poachers, Table 2 and introduction of revenue sharing scheme. However, the respondents illustrated that despite the reduction of poaching cases in the Volcanoes National Park after the introduction of revenue sharing scheme in 2005, human-wildlife conflicts which sometimes happen in the area around the park, and animals, especially baboon and buffalo damage local communities' properties and crops which threaten wildlife conservation in the area through human and wildlife conflicts.

The buffalo wall stone which was built around the park in 2016, initially as a boundary marker between the national and surrounding areas, and was modified and extended to act as a deterrent against crop raiding animals, particularly buffaloes, did not bring a reliable solution to this problem. 


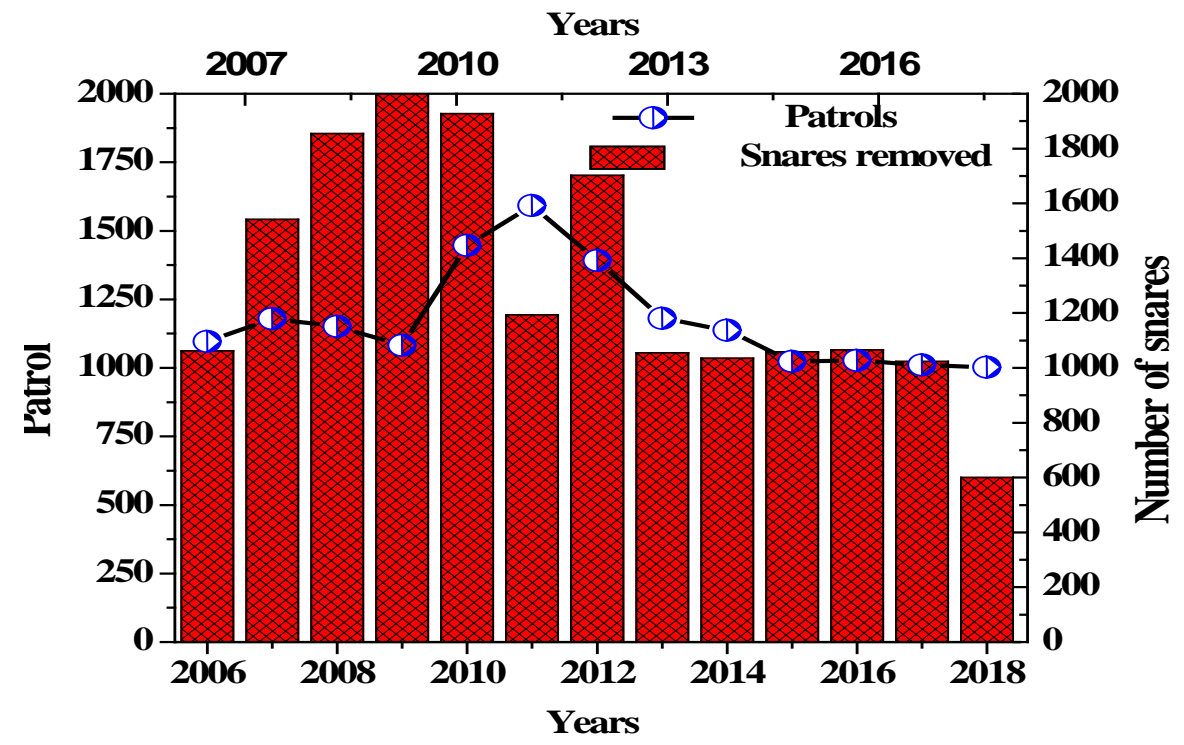

Figure 2. Poaching situation in the VNP since the introduction of Revenue Sharing Policy.

Table 3. Proportional of poachers in Shingiro and other sectors of Musanze district.

\begin{tabular}{cccccc}
\hline Years & Patrols & Snares removed & Area & $\begin{array}{c}\text { Number of } \\
\text { poachers arrested }\end{array}$ & Sectors of origin \\
\hline 2006 & 1096 & 1062 & VNP & 12 & Kinigi \& Shingiro \\
2007 & 1179 & 1542 & VNP & 15 & Shingiro \& Cyuve \\
2008 & 1151 & 1855 & VNP & 6 & Kinigi \& Shingiro \\
2009 & 1082 & 2010 & VNP & 8 & Shingiro \\
2010 & 1447 & 1927 & VNP & 0 & - \\
2011 & 1592 & 1194 & VNP & 4 & Shingiro \\
2012 & 1392 & 1702 & VNP & 6 & Shingiro \\
2013 & 1180 & 1055 & VNP & 18 & Shingiro \\
2014 & 1137 & 1035 & VNP & 2 & Syange \\
2015 & 1023 & 1059 & VNP & 3 & Shingiro \\
2016 & 1027 & 1066 & VNP & 7 & Shingiro \& Kinigi \\
2017 & 1010 & 1023 & VNP & 0 & 3 \\
2018 & 1002 & 600 & VNP & &
\end{tabular}

Source: RDB, 2019.

Some approaches to deal with this problem included the establishment of the Special Guarantee Fund (SGF) as a public institution which was previously known as Automobile Guarantee Fund created as an autonomous body in 2002 to compensate victims of road accidents caused by non-insured and non-identified vehicles. However, since December 2011, its mandate was extended to compensate victims of wild animals' damages in areas that are in close proximity with national parks. 


\subsection{Former Poachers' Perception on Conservation of Wildlife in the Volcanoes National Park}

Revenue Sharing Program which was introduced by Rwanda Development Board (RDB) in 2005 as one of the important strategies to improve living conditions of local communities around the national parks, and also as a way to motivate former poachers to participate in protection of the parks, its implementation has significantly changed the former poachers' behaviors towards wildlife conservation in the Volcanoes National Park where, many of them including 45 members of the Gorilla Guardian Village decided to become wildlife conservation preachers.

After the implementation of some conservation measures undertaken by the government including Revenue Sharing Scheme, construction of buffalo wall stone around the park as a solution to human-wildlife conflicts, these projects involving local communities especially the former poachers in protection of the park where some work as park rangers, educating local communities about the role of wildlife protection, expanding the buffer zone area, introduction of Special Guarantee Fund to compensate the victims of wild animals damages, and introduction of Revenue Sharing Scheme where, $10 \%$ of the park's revenues is given to the local communities living adjacent to the park, as it is indicated by the findings in Table 3, these measures have not up to now brought the final solutions to the problem of poaching in the Volcanoes National Park.

Also some of the main causes that push some local people to continue poaching activities have been addressed by the respondents. Thus, the respondents tried to clarify their points of views on what the government together with all concerned stakeholders must do as additional measures to ensure maximum conservation of wildlife in the park. The respondents proposed the construction of a strong fence around the Volcanoes National Park as it was done to Akagera National Park; which at present is electrically fenced (Bariyanga et al., 2016).

The respondents addressed that; it will be more helpful if wildlife conservation-related subjects are added in the curricula and taught to all students from primary schools to university level. In addition to this, wildlife protection laws should be sufficiently explained to all citizens. Finally, it is suggested to organize annual competitions on wildlife conservation projects by rewarding the best performers.

\section{Conclusion}

The aim of this study was to assess the contribution of the former poachers for conservation of wildlife in Volcanoes National Park with the Gorilla Guardian Village as study area, the findings indicated that the contribution of former poachers is highly significant in both tourism and environmental sectors especially after giving up such illegal activities, they decided to become wildlife conservation preachers due to a number of benefits they earn such as employment opportunities, improvement of living conditions, and infrastructure development through effective implementation of revenue sharing scheme introduced 
by Rwanda Development Board (RDB) in 2005. However, even if the local communities around the Volcanoes National Park, especially those living in Kinigi Sector where the research was conducted, the population seem to already have changed their perception on wildlife conservation, poaching and other illegal activities in the park will be totally eliminated in many sectors surrounding the Volcanoes National Park, but there is still a need to reinforce conservation efforts in Shingiro Sector where the results indicated high number of poachers. Normally, there are 12 sectors in four districts such as Burera, Kinigi, Rubavu and Nyabihu which share border with the Volcanoes National Park; however, due to the limited time and money during the research, this study was conducted in one sector in Musanze District. Therefore, more research is recommended in four different districts to get more additional data on poaching and wildlife conservation-related issues in the volcanic region.

\section{Acknowledgements}

I am thankful to Rwanda Development Board, Volcanoes National Park Head Office/Kinigi, Gorilla Guardian Village, and Kinigi Sector Executive Secretaries for accepting to providing information that were used to this study.

\section{Conflicts of Interest}

The authors declare no conflicts of interest regarding the publication of this paper.

\section{References}

Archabald, K., \& Naughton-Treves, L. (2001). Tourism Revenue-Sharing around National Parks in Western Uganda: Early Efforts to Identify and Reward Local Communities. Environmental Conservation, 28, 135-149. https://doi.org/10.1017/S0376892901000145

Bariyanga, J. D., Wronski, T., Plath, M., \& Apio, A. (2016). Effectiveness of Electro-Fencing for Restricting the Ranging Behaviour of Wildlife: A Case Study in the Degazetted Parts of Akagera National Park. African Zoology, 51, 183-191. https://doi.org/10.1080/15627020.2016.1249954

Beck, J. M., Lopez, M. C., Mudumba, T., \& Montgomery, R. A. (2019). Improving Human-Lion Conflict Research through Interdisciplinarity. Frontiers in Ecology and Evolution, 7, 243. https://doi.org/10.3389/fevo.2019.00243

Collins, C., \& Kays, R. (2011). Causes of Mortality in North American Populations of Large and Medium-Sized Mammals. Animal Conservation, 14, 474-483. https://doi.org/10.1111/j.1469-1795.2011.00458.x

Imanishimwe, A., Niyonzima, T., \& Nsabimana, D. (2018). Contribution of Community Conservation and Ecotourism Projects on Improving Livelihoods and Sustainable Biodiversity Conservation in and around Nyungwe National Park (NNP). Journal of Tourism \& Hospitality, 7, 363. https://doi.org/10.4172/2167-0269.1000363

Jones, J. A., Creed, I. F., Hatcher, K. L., Warren, R. J., Adams, M. B., Benson, M. H., Boose, E., Brown, W. A., Campbell, J. L., \& Covich, A. (2012). Ecosystem Processes and Human Influences Regulate Streamflow Response to Climate Change at Long-Term Ecological Research Sites. BioScience, 62, 390-404.

https://doi.org/10.1525/bio.2012.62.4.10 
Kagarama, J., Bizoza, A., \& Kayigamba, C. (2012). Assessment of Performance of the Revenue Sharing Implementation during 2005-2010. Kigali: Rwanda Development Board.

Knapp, E. J., Peace, N., \& Bechtel, L. (2017). Poachers and Poverty: Assessing Objective and Subjective Measures of Poverty among Illegal Hunters outside Ruaha National Park, Tanzania. Conservation and Society, 15, 24-32. https://doi.org/10.4103/0972-4923.201393

Lewis, J. S., Logan, K. A., Alldredge, M. W., Carver, S., Bevins, S. N., Lappin, M., VandeWoude, S., \& Crooks, K. R. (2017). The Effects of Demographic, Social, and Environmental Characteristics on Pathogen Prevalence in Wild Felids across a Gradient of Urbanization. PLoS ONE, 12, e0187035. https://doi.org/10.1371/journal.pone.0187035

Maingi, J. K., Mukeka, J. M., Kyale, D. M., \& Muasya, R. M. (2012). Spatiotemporal Patterns of Elephant Poaching in South-Eastern Kenya. Wildlife Research, 39, 234-249. https://doi.org/10.1071/WR11017

Matinca, A. (2018). Human-Wildlife Conflict in Northeastern Namibia. CITES, Elephant Conservation and Local Livelihoods, Universität zu Köln.

Mentan, T. (2017). Dilemmas of Weak States: Africa and Transnational Terrorism in the Twenty-First Century. Abingdon-on-Thames: Routledge. https://doi.org/10.4324/9781351159920

Munanura, I. E., Backman, K. F., Hallo, J. C., \& Powell, R. B. (2016). Perceptions of Tourism Revenue Sharing Impacts on Volcanoes National Park, Rwanda: A Sustainable Livelihoods Framework. Journal of Sustainable Tourism, 24, 1709-1726. https://doi.org/10.1080/09669582.2016.1145228

Murali (2017). Environmental Management: Science and Engineering for Industry. Oxford: Elsevier Science.

Njuguna, M., \& Deisser, A.-M. (2016). Conservation of Natural and Cultural Heritage in Kenya. UCL Press.

Richard, E. (2000). Tiger Bone \&Rhino Horn: The Destruction of Wildlife for Traditional Chinese Medicine. Washington DC: Island Press.

Samedi, M., Eckardt, W., Derhé, M., Miller, M., Grueter, C., Robbins, M., \& Nsabimana, D. (2019). Effect of Mountain Gorilla (Gorilla beringei beringei) Population Growth to Their Key Food Plant Biomass in Volcanoes National Park, Rwanda. Rwanda Journal of Engineering, Science, Technology and Environment, 2, No. 1.

Schauer, J. (2019). Wildlife between Empire and Nation in Twentieth-Century Africa. Berlin: Springer. https://doi.org/10.1007/978-3-030-02883-1

Slovin, E. (1960). Slovin's Formula for Sampling Technique.

Warchol, G. (2017). Exploiting the Wilderness: An Analysis of Wildlife Crime.

William, A. (2018). Smallholder Farmers, Environmental Change and Adaptation in a Human-Dominated Landscape in the Northern Highlands of Rwanda. Yellow Springs, $\mathrm{OH}$ : Antioch University. 